\title{
Fisheries for orange roughy (Hoplostethus atlanticus) on seamounts in New Zealand
}

\author{
Malcolm CLARK* \\ National Institute of Water and Atmospheric Research, P O Box 14-901, Wellington, New Zealand \\ Revised 15 March 1999; accepted 16 April 1999
}

\begin{abstract}
Major commercial fisheries for orange roughy (Hoplostethus atlanticus) occur on seamount features, which are widely distributed throughout the New Zealand region. When the fishery developed in the late 1970s to early 1980s, it occurred mainly on flat bottom, but over time has become more focused on seamounts. In the 1995-1996 fishing year, it is estimated that about $70 \%$ of the catch of orange roughy within the New Zealand EEZ was taken from seamounts. Seamounts on the Chatham Rise have been fished for over ten years. Examination of commercial catch and effort data show strong declines in catch rates over time, and a pattern of serial depletion of seamount populations, with the fishery moving progressively eastwards to unfished seamounts along the southern margins of the Rise. Catch rates on seamounts in other regions of New Zealand have also generally shown a similar pattern of rapid decline. There is growing concern over the impact of trawling on seamounts, and the effects this can have on the benthic habitat and fauna, and the long-term sustainability of associated commercial fisheries. (C) 1999 Ifremer / CNRS / IRD / Éditions scientifiques et médicales Elsevier SAS
\end{abstract}

\section{orange roughy / Hoplostethus atlanticus / seamounts / fisheries / New Zealand}

Résumé - Pêcheries d'orange roughy (Hoplostethus atlanticus) sur les monts sous-marins de Nouvelle-Zélande. Les plus importantes pêcheries d'orange roughy (Hoplostethus atlanticus) sont situées sur les monts sous-marins, nombreux dans les eaux néo-zélandaises. La pêche a commencé à la fin des années 1970-début 1980 sur les zones à fond plat. Ensuite, elle s'est cléplacée sur les monts sous-marins où, pendant la campagne 1995-1996, ont été effectuées $70 \%$ des prises d'orange roughy de la zone économique exclusive de Nouvelle-Zélande. Les monts sous-marins de la ride de Chatham ont été exploités pendant plus de 10 ans. L'analyse des captures commerciales et de l'effort de pêche montre une nette diminution au cours du temps et une série d'épuisements des populations des monts sous-marins avec le déplacement progressif des zones de pêche vers l'est, le long des marges sud de la ride de Chatham. Les taux de captures sur les monts sousmarins d'autres régions de Nouvelle-Zélande sont aussi en décroissance rapide. L'inquiétude grandit au sujet des conséquences du chalutage sur l'habitat de la faune benthique, des monts sous-marins et sur l'avenir à long terme des pêcheries commerciales. (C) 1999 Ifremer / CNRS / IRD / Éditions scientifiques et médicales Elsevier SAS

orange roughy / Hoplostethus atlanticus / monts sous-marins / pêcheries / Nouvelle-Zélande

\section{INTRODUCTION}

Seamounts are widely regarded as areas of high productivity, and often host aggregations of fish which form the basis of commercial fisheries. Such fisheries include rockfish (Sebastes spp.), alfonsino (Beryx splendens), pelagic armourhead (Pseudopentaceros wheeleri), and sea bass/pink maomao (Caprodon longimanus) in the Pacific Ocean [16, 17]. In waters around New Zealand, seamounts are the focus for bottom trawl fisheries for orange roughy (Hoplostethus atlanticus) and oreo (Allocyttus niger, Pseudocyttus maculatus) at depths of $600 \mathrm{~m}$ to $1200 \mathrm{~m}$. The fishery for orange roughy is the subject of this paper.

\footnotetext{
" Correspondence and reprints: m.clark@niwa.cri.nz
} 


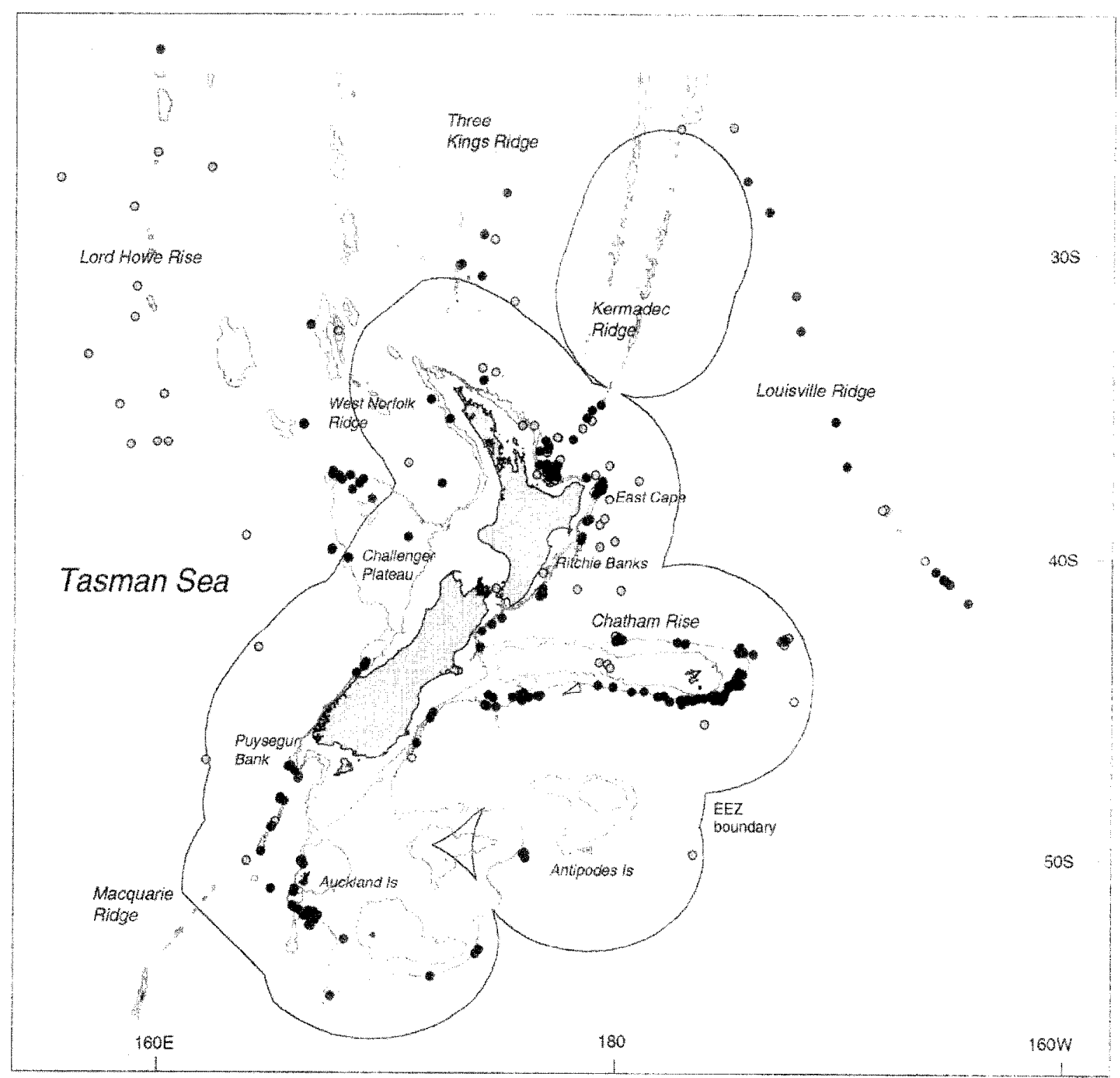

Figure 1. Distribution of seamounts within the New Zealand region, and location of features referred to in the text (seamounts with peaks at 500-1000 m depth are coloured black, shallower or deeper are grey; 500 and $1000 \mathrm{~m}$ contours are shown).

\section{SEAMOUNT DISTRIBUTION AROUND NEW ZEALAND}

The New Zealand region has a very complex bathymetry. It sits astride a tectonic plate boundary, so the region has active volcanics, ridge formation, and subduction, as well as older intra-plate volcanics on plateaux and rises to the west, and southeast. This results in a large number of seamount-type formations, with a range of ages from 0.01 to 80 million years. They are scattered all around the New
Zealand region, both inshore along the east coast, and offshore along the major bathymetric features such as Kermadec Ridge, Three Kings Ridge, Lord Howe Rise, West Norfolk Ridge, Macquarie Ridge, the Chatham Rise, and the Louisville Ridge to the cast (figure 1).

Strictly defined, 'seamounts' are features with relief over $1000 \mathrm{~m}$, with 'knolls' and 'hills' being less than this. However, following common usage $[7,16]$ seamounts are dcfined here as topographic 'hill' features regardless of size. Knolls and hills, with a vertical extent of $200-300 \mathrm{~m}$ 
above the seafloor are important for fisheries. Shape and size of these varies considerably, from steep-sided 'pinnacles' with slope angles of $20-30^{\circ}$, to more gentle slopes where the seamounts may be several kilometres across the base.

For deepwater fisheries, the depth of the seamount is important. Figure I highlights the features with peaks between $500 \mathrm{~m}$ and $1000 \mathrm{~m}$. This is the depth range of seamounts that host orange roughy and oreos. This is not a comprehensive set of features, as it has been compiled to show their overall geographic spread, and recent, more detailed bathymetric mapping and swathe work has covered extensive new areas.

\section{ORANGE ROUGHY FISHERIES IN NEW ZEALAND}

Orange roughy occur throughout New Zealand waters at depths between $700 \mathrm{~m}$ and $1500 \mathrm{~m}$ [2]. The fish form large aggregations for either spawning or feeding, and these are the targets of commercial fishing using bottom trawl gear. There are seven major fishing grounds within the New Zealand 200 mile Exclusive Economic Zone (EEZ), with additional fishing grounds outside the EEZ on the Lord Howe Rise and Louisville Ridge. The main fishing areas have historically been the Chatham Rise, Challenger Plateau, and the Ritchie Banks which developed progressively from 1979 through the mid-1980s. For much of the 1980 s, total reported catches have been of the order of $40-$ 50000 t. Quota reductions in recent years now allow an annual level of catch of about $20000 \mathrm{t}$. The fishery has an export value of about NZ\$125 million, which makes it a very valuable and sought-after commercial species.

Orange roughy form aggregations in known locations at predictable times of the year, and so can be easily found and fished, and consequently can rapidly be overfished [2]. Orange roughy have a high longevity, slow growth rate, low fecundity $[4,14,18,19]$, and little is known about recruitment processes, which make recovery from overfishing slow, and uncertain. This means that the fisheries need to be carefully researched, monitored and managed to reduce the chances of stock, and fishery, collapse.

\section{DISTRIBUTION OF FISHERIES ON SEAMOUNTS}

Many of the fisheries for orange roughy around New Zealand currently occur on seamounts. However, it has been a progressive development. During the mid-1980s, when the fisheries were still relatively new (figure 2, upper panel) most fisheries occurred on the flat bottom of the continental slope. The majority of the catch (as indicated by the catch rate distribution) on the Challenger Plateau, and out along the Chatham Rise came from the slope, even though seamounts were known in other areas. Aggregations occurred on bottom which could be easily trawled with little risk of damage to fishing gear. But seamount features had begun to be fished off the east coast of the North Island and along the southern Chatham Rise.

By 1988, more seamounts on the Challenger and along the eastern and southern slopes of the Chatham Rise were being worked (figure 2, middle panel). This was because some of the slope grounds were becoming overexploited, as more was learnt about the association of orange roughy and hills, and as GPS navigation was developed enabling small features to be targeted and trawled successfully.

In the last few years seamounts have become the main focus for orange roughy fishing (figure 2, lower panel). The fishery is now concentrated on hills out on the Challenger Plateau and Lord Howe Rise, around the northern North Island and East Cape, the Louisville Ridge, northwestern and eastern Chatham Rise and off Puysegur Bank and the Antipodes Islands in southern regions of the EEZ. This has come about through further refinement in navigational and electronic fishing equipment, and more cxploratory fishing sometimes in areas where bathymetric surveys had indicated the presence of seamounts.

The current distribution of the fishery results in the majority of catch being taken on seamounts (table I). Most areas feature a range of bottom types (seamount/ flat/drop-off), and quite a variable proportion of catch from seamount features. Of the major fisheries, seamount catch dominates the Chatham Rise (although the Spawning Box area is flat, with an increasing proportion of catch since 1995/96), the East coast, with East Cape and Ritchie Banks complexes, and southern parts of the EEZ. Fisheries outside the EEZ, on the Louisville Ridge and Northwest Challenger Plateau, are primarily seamount fisheries, and a catch of around $10000 \mathrm{t}$ per year is currently taken by New Zealand vessels. Overall, about $70 \%$ of the catch in the New Zealand orange roughy fishery is now taken on seamount features.

\section{THE CHATHAM RISE SEAMOUNT FISHERY}

For almost all of the 15-20 ycars of orange roughy fishing in New Zealand the Chatham Rise has been the most 


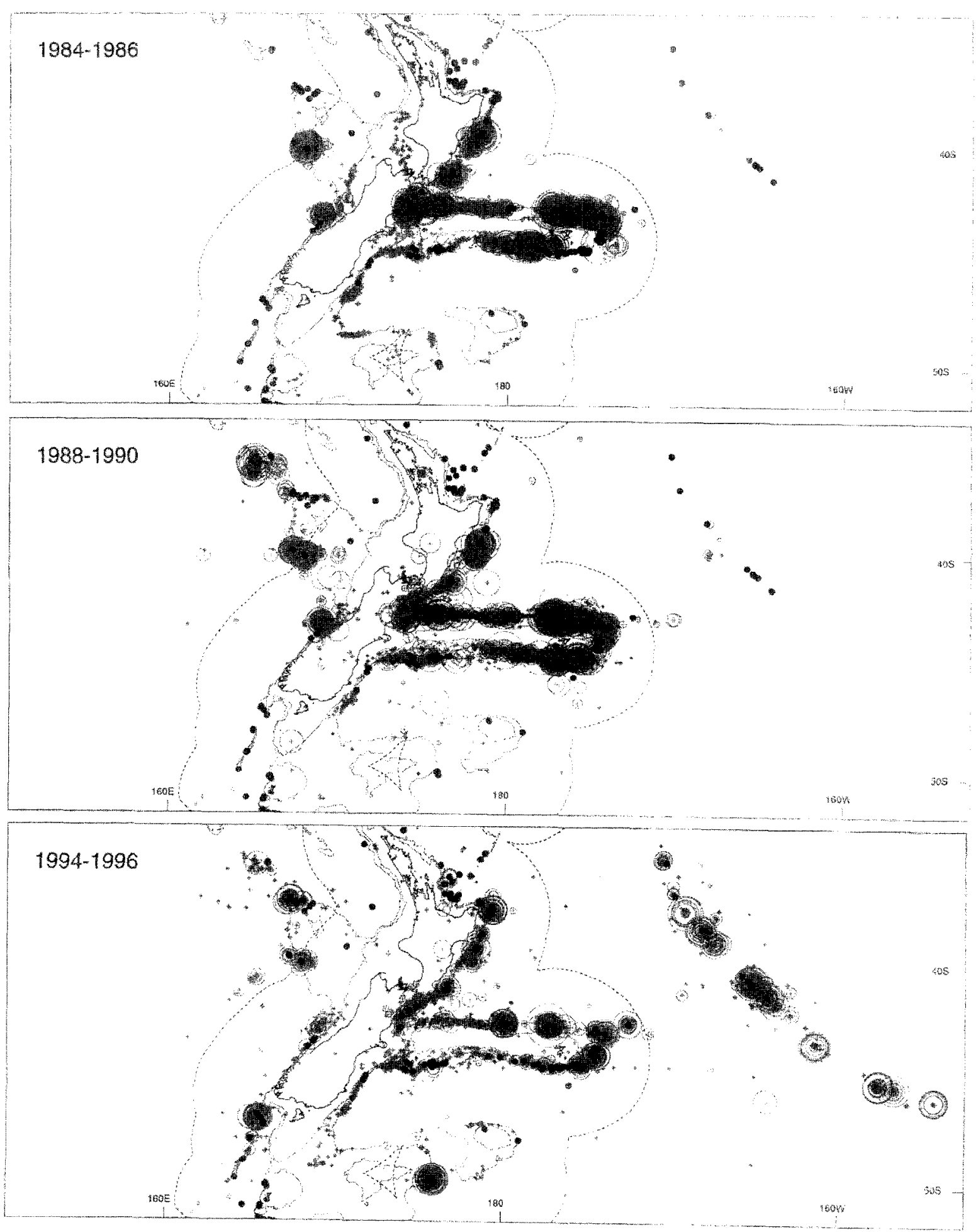

Figure 2. Distribution of orange roughy catch rate in relation to seamounts for three time periods: 1984/85 1985/86 tishing years (top), 1988/89-1989/90 fishing years (middle), and 1994/95-1995/96 (bottom). Seamounts of 500-1000 m depth are shown as black dots; 500 m and $1000 \mathrm{~m}$ contours, and EEZ boundaries are shown; each circle is a catch per tow proportional to a maximum catch of $90 \mathrm{t}$ per trawl. 
Table I. Summary by region of bottom type, catch of orange roughy (1995/96 fishing year in tonnes), and approximate percentage of that catch taken from seamounts $(\mathrm{S}=$ seamount, $\mathrm{F}=$ flat bottom, $\mathrm{D}$ $=$ drop-off feature).

\begin{tabular}{|c|c|c|c|}
\hline Region & $\begin{array}{l}\text { Bottom } \\
\text { type }\end{array}$ & $\begin{array}{l}\text { Catch }(t) \\
(1995 / 96)\end{array}$ & $\begin{array}{c}\% \\
\text { seamount }\end{array}$ \\
\hline \multicolumn{4}{|l|}{ CHATHAM RISE } \\
\hline Northwest & S F D & 2500 & 70 \\
\hline Spawning Box & $\Gamma \mathrm{S}$ & 1700 & 10 \\
\hline East & S F & 2300 & 90 \\
\hline South & $S$ & 1400 & 85 \\
\hline \multicolumn{4}{|l|}{ EAST COAST } \\
\hline East Cape & $\mathrm{S}$ & 3100 & 100 \\
\hline Ritchie & S F & 1150 & 75 \\
\hline Wairarapa & S F & 250 & 50 \\
\hline Kaikoura & $S$ & 600 & 100 \\
\hline \multicolumn{4}{|c|}{ CHALLENGER PLATEAU } \\
\hline Southwest & F S & 1670 & 45 \\
\hline \multicolumn{4}{|c|}{ WEST COAST SOUTH ISLAND } \\
\hline Cook Canyon & D F & 400 & 0 \\
\hline \multicolumn{4}{|l|}{ SOUTHERN EEZ } \\
\hline Puysegur & S D & 800 & 50 \\
\hline Auckland & $\mathrm{S}$ & 450 & 100 \\
\hline Antipodes & S F & 3300 & 75 \\
\hline Arrow & $\mathrm{S}$ & 200 & 100 \\
\hline \multicolumn{4}{|c|}{ NOR'IHERN NORI'H ISLAND } \\
\hline $\begin{array}{l}\text { Bay } \\
\text { of Plenty }\end{array}$ & S & 1000 & 100 \\
\hline OVERALL SEAMOUY. & EATURES & & oprox. 70 \\
\hline
\end{tabular}

important fishing area, with annual catches (from both slope and seamounts) of 20-30000 t. The Rise is a ridge extending eastwards from the South Island of New Zealand, at depths of $200-300 \mathrm{~m}$ on top, and dropping to over $2000 \mathrm{~m}$ on the flanks. It has a large number of smaller knolls and hills, which are often clustered in multiple-peak complexes. Major groups of seamounts are shown in figure 3; the 'Graveyard' in the northwest, 'Smiths City' in the northeast, the 'Andes' to the east, 'Big Chief' to the southeast, and a string of hills along the southern flank.

To show changes in the fishery over time, an axis (like a string line) has been drawn along the $1000 \mathrm{~m}$ line in the north, bent around to the south, and back to the west. All the tow locations for orange roughy are shifted to the nearest point on this line, which enables a simple graphical presentation (figure 4).

The fishery initially focused on flat ground (east of $180^{\circ}$ on the North Rise, and not seen in figure 4, which plots only seamount catch) which gave almost all the catch, but from the early-mid 1980s (82/84-85/87) hills began to be fished east of $180^{\circ}$ on the South Chatham Rise. By 1995/ 1996 seamounts contributed about $65 \%$ of the total Chatham Rise catch. Only a small number of seamounts were fished at first, but from 1988 things started to change, as seen in the sharp peaks of the plots. A narrow peak effectively means a seamount group. The number of seamounts fished increased dramatically, as the catch rose from the southern and eastern parts of the Rise. Catches fcll away around $180^{\circ}$ as hills further east on the South Rise were fished (moving towards 'Big Chief' out on the southeastern corner), as catch rates declined on the older hills [8]. The plot for 1991/93 shows the spikes moving more to the left, which represents the fishery advancing around the corner onto the East Rise as the 'Andes' fishery developed. Trawls have continued to be made frequently on most of the seamounts, but catches have since declined as the hills became overexploited, and the fishery has moved on. New hills $\left(180^{\circ}\right.$ on the North Rise - 'Graveyard' complex) have since developed. There is no strong indication of any recovery in catch rates on the older hills over time. The Chatham Rise has been extensively covered in recent years with swath-mapping surveys, and so it appears unlikely that further new features will be found. The efforts of the deepwater fishing industry have since moved on to other regions of the New Zealand EEZ.

The most recent stock assessment of this fishery indicates that it is fully developed. Some stocks are overexploited, with the Spawning Box and East Rise populations estimated at $20-30 \%$ of virgin levels [1]. Some populations (e.g. 'Graveyard' orange roughy) may still be in a fishing-down phase, and above long-term sustainable biomass levels.

The fishing down of seamount-based stocks is clear in figure 5, where unstandardised catch per tow (catch per distance is not appropriate with steep hills and short tow duration) is plotted by year for the main Chatham Rise hill complexes. All show a trend of decreasing catch rates. Catch rates have shown a small increase in the last year on two seamounts, although it is unknown whether this is just a temporary perturbation in the downwards trend, a real increase of abundance, or duc to reductions in effort and fishing pressure, with less disruption to the aggregation behaviour of orange roughy.

It is recognised that changes in CPUE of orange roughy may not track changes in real abundance very closely. Standardised analysis of Chatham Rise CPUE data has 


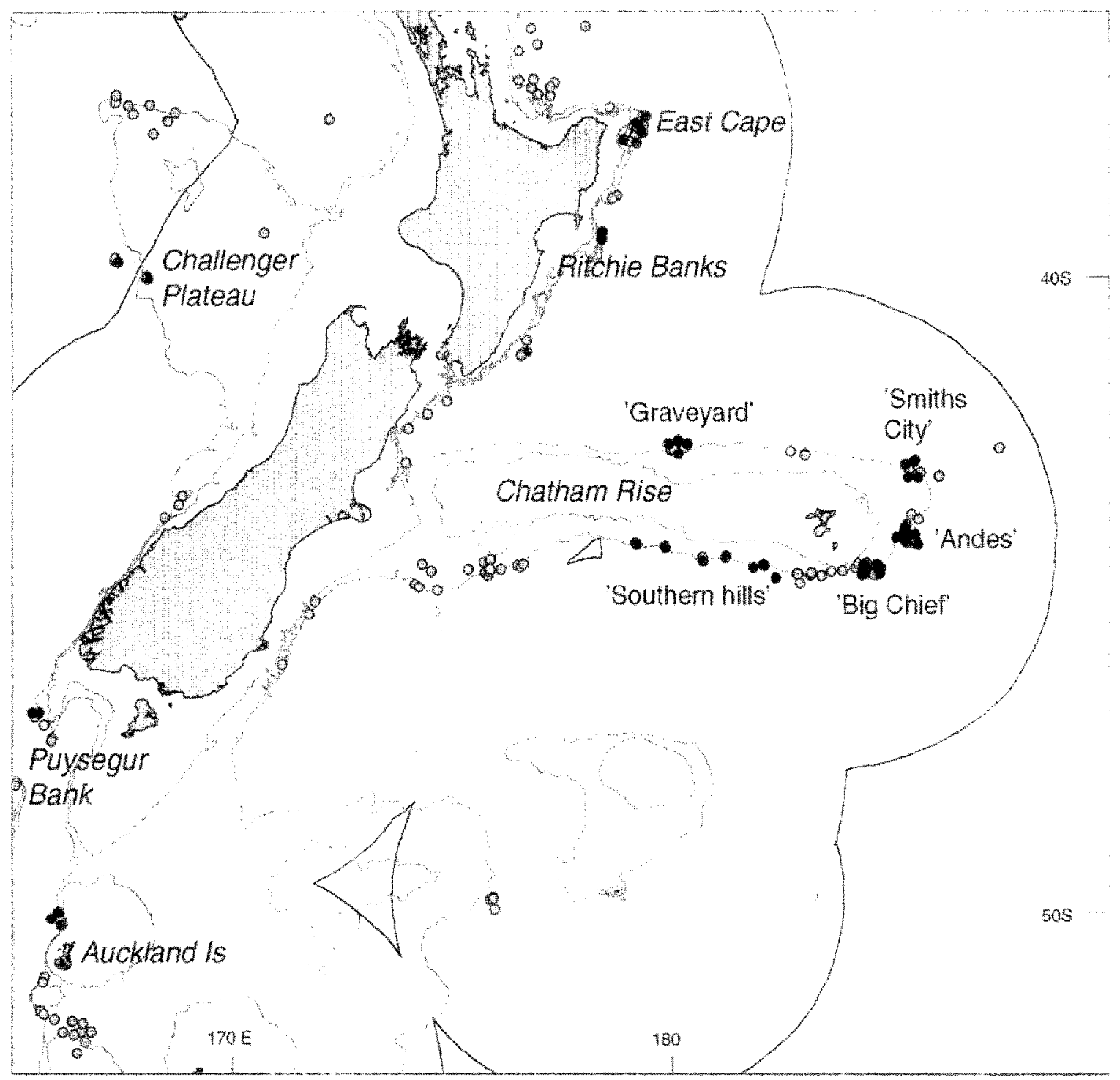

Figure 3. Location of seamount features on the Chatham Rise ('Graveyard', 'Smith's City', 'Andes', 'Big Chief', and several 'Southern hills'), as well as other features in New Zealand waters where catch-effort data are presented.

shown that catch rates (and abundance indices) for the spawning period fishery remained high, and for several years was relatively flat despite stock assessment indicating a substantial decline in biomass of the stock $[6,9]$. This suggested that the ability of fishers to target aggregations, as well as the use of burst panels to limit the amount of fish caught, could have masked a decline in abundance [3]. This implies that CPUE declines for orange roughy can in some situations under-represent true decreases in abundance.

\section{CHANGES ON OTHER SEAMOUNTS}

The pattern of rapid decline in catch rates of orange roughy evident on the Chatham Rise seems to be typical of seamount fisheries. There appears to be limited predictive ability with new fisheries to guide appropriate catch levels for orange roughy. The extent of changes, and how long they take, have been variable and inconsistent on New Zcaland scamounts. Catch-cffort data from other seamounts have been examined (see figure 3); East Cape 

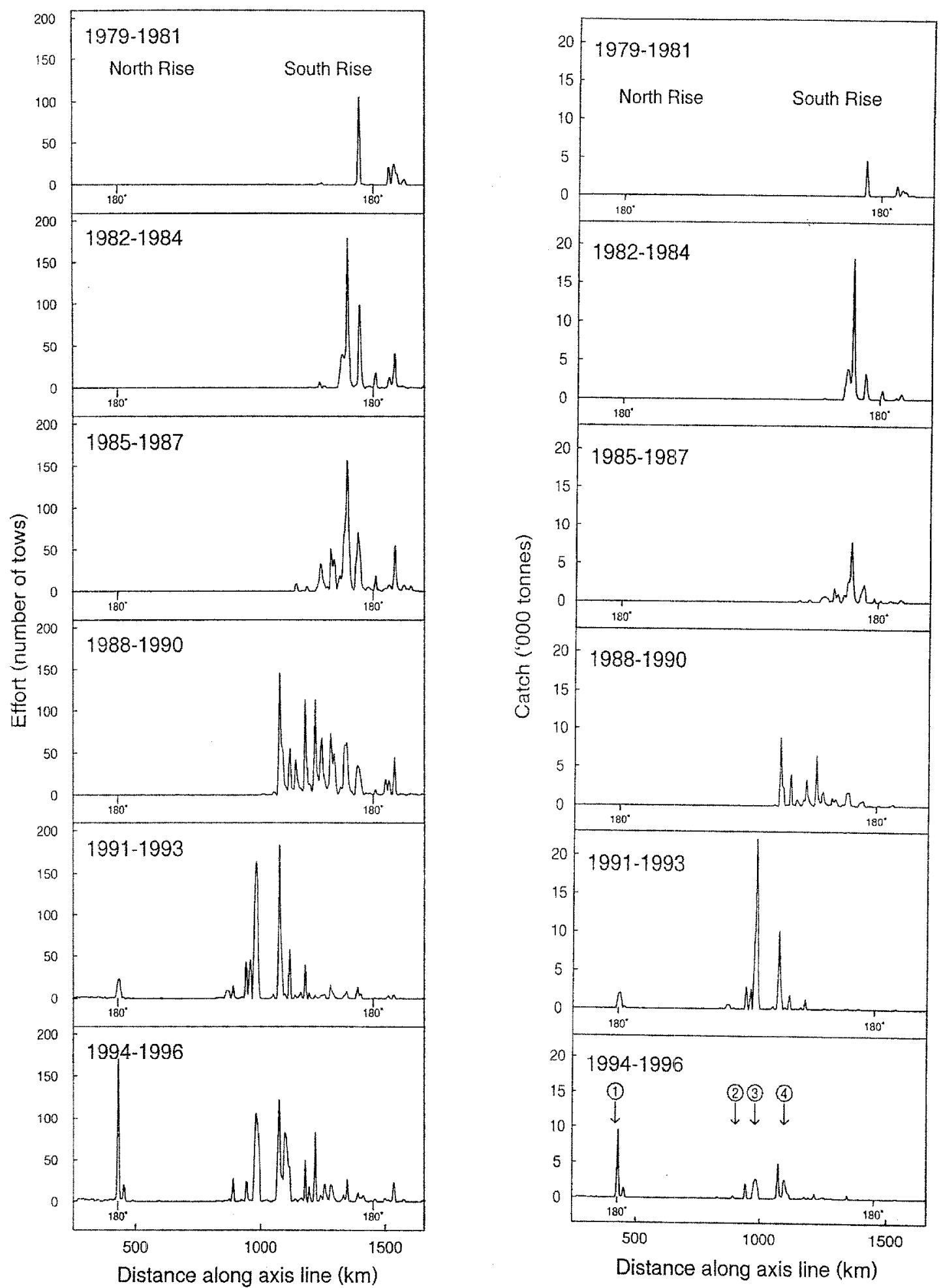

Figure 4. Changes in effort (left panel) and catch (right panel) of orange roughy on seamounts of the Chatham Rise. (effort = number of tows, calch = tonnes; the left hand side of the plot represents the nor hiwest conner of the Rise, the right hand side is the southwest corner; key seamounts are labelled for reference (see figure 3): 1='Graveyard', 2='Smiths City', 3='Andes', 4= 'Big Chief'). 


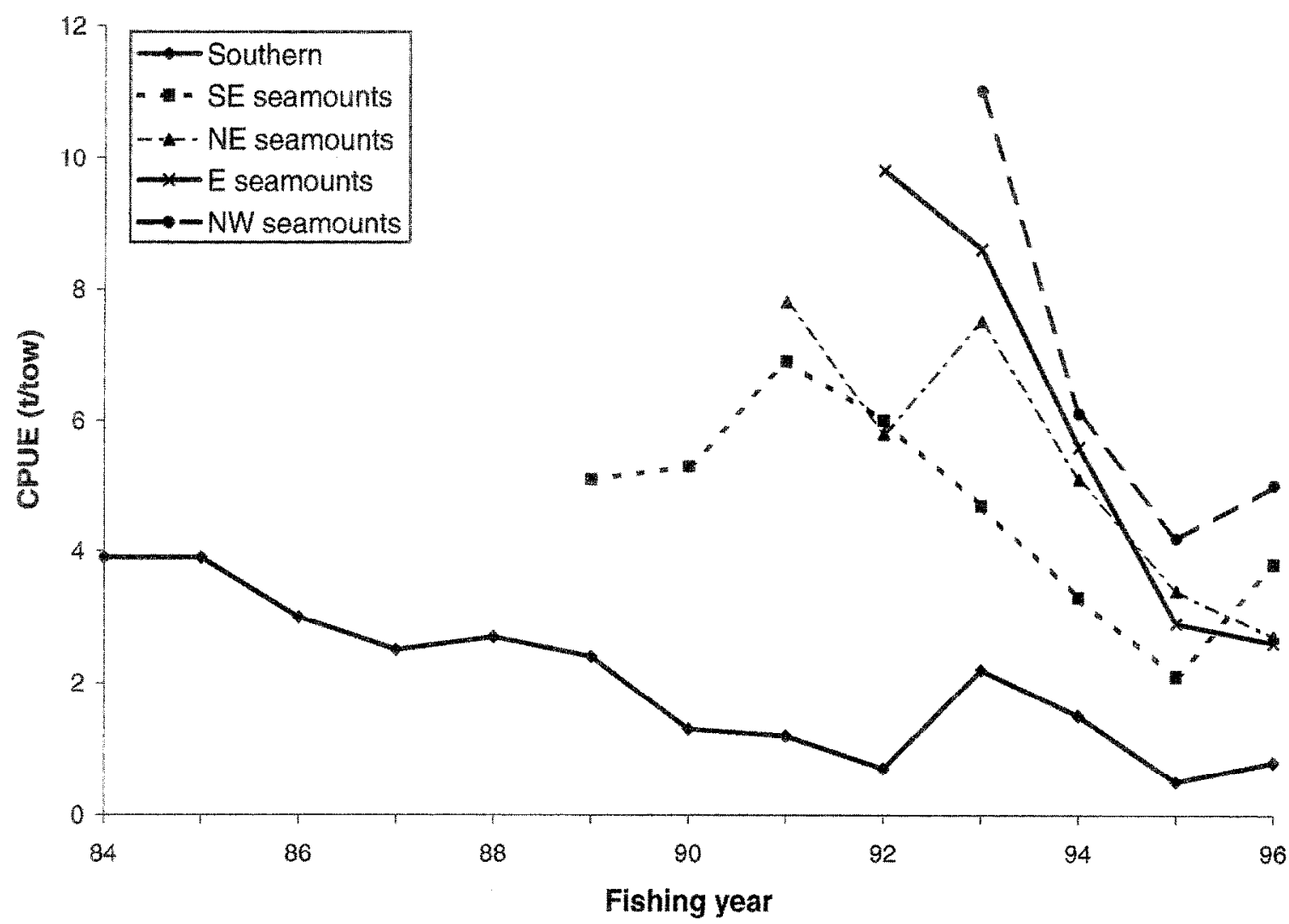

Figure 5. Changes in catch per unit of effort of orange roughy over time on Chatham Rise seamounts (average catch per tow for all tows in the fishery for a year).

and Ritchie Banks off the east coast of the North Island, the Challenger Plateau to the west, and Puysegur Bank and Auckland Island features to the south. These are all fairly small features, similar in size, and cover a wide geographic range.

Changes in catch rates are summarised in table II. For each seamount, the number of years fished and the average catch per year over that time are given, with the extent of decline in catch per tow in the 1995/96 fishing year compared with the maximum in early years. The Chatham Rise hills have generally been quite heavily fished (several thousand tonnes per year), and CPUE has dropped substantially on the South Rise hills and 'Andes'. Other large volume fisheries have had mixed results. The Challenger Plateau seamount fishery has stood up well over eleven years, but that on the Ritchie Banks has almost collapsed. Catch rates on the Puysegur Bank hills crashed after a short time, with in the case of 'Godiva' a very small level of catch.

Changes in catch rates to low levels within several years (and for all New Zealand roughy fisheries within 5-10 years) indicates that orange roughy stocks might not maintain stable fisheries and high catches during the initial years while research and management catch up with the fishery. Serial depletion, and overfishing, can happen very rapidly. Broad area quota limits (in New Zealand Total Allowable Catches, TACs) do not protect individual seamounts against overfishing. Individual feature catch limits is one option for management, and this has been applied to exploratory fishing for orange roughy in areas east of the Chatham Rise, and in northern Ncw Zcaland waters. However, there has to be a balance in the practical scale of management units.

\section{IMPACTS OF FISHING ON SEAMOUNTS}

There is widespread and growing awareness of the environmental impacts of fishing activities $[5,10]$. Deepwater seamounts often have a diverse and unusual fauna [15], but faunal assemblages may be less productive and potentially more sensitive to disruption than in shallow water 
Table II. Summary of number of years fishing, catch per year, and change over time in catch per unit effort (CPUE) of orange roughy for a number of New Zealand seamounts.

\begin{tabular}{lccc}
\hline Seamount & $\begin{array}{c}\text { No. } \\
\text { of years } \\
\text { (to 1995/96) }\end{array}$ & $\begin{array}{c}\text { Average } \\
\text { catch } \\
\text { (t/year) }\end{array}$ & $\begin{array}{c}\text { CPUE } \\
\text { (last yr } \\
\text { max. yr) }\end{array}$ \\
\hline CHATHAM RISE & & & \\
Graveyard & 4 & 2200 & 0.45 \\
Andes & 5 & 3200 & 0.26 \\
Big Chief & 8 & 1800 & 0.55 \\
Smiths City & 6 & 1500 & 0.35 \\
Southern hills & 13 & 2800 & 0.20 \\
CHALLENGER PLATEAU & & & \\
MegaBrick/TT & 11 & 1500 & 0.29 \\
Westpac & 4 & 400 & 1.00 \\
PUYSEGUR BANK & & & \\
Godiva & 5 & 300 & 0.21 \\
Goomzy & 5 & 1400 & 0.11 \\
AUCKLAND ISLANDS & & & \\
DSW hills & 4 & 500 & 0.40 \\
EAST COAST & & & 0.10 \\
Ritchie Hill & 11 & 2500 & 0.53 \\
East Cape & 3 & 3200 & \\
\hline
\end{tabular}

habitats. Seamounts are widely regarded as productive, but fragile habitats $[11,16,20]$. Indications are that the habitat and its associated fauna are vulnerable, and trawl fisheries may have significant and long-lasting impacts which could in turn affect the sustainability of deepwater marine fisheries.

This is of concern to New Zealand with its rapid development of deepwater trawl fisheries for species like orange roughy and oreo. When targeting aggregations of fish, commercial fishing vessels carry out a large number of trawls in very small areas, thereby potentially causing severe localised impact on the benthos. These fisheries, and new exploratory fishing, are becoming more and more focused on seamount features. To date in New Zealand there has been little work carried out offshore, but personal observations tell a familiar story. In the early days of fishing on a seamount, catch of benthic fauna (corals, sponges, crinoids, holothurians, echinoderms, crabs etc.) was often considerable. But, after several years of trawling, the picture is very different, with very little sessile benthic fauna caught in trawls. Part of the reason is very likely the trawl gear used, which in New Zealand features very heavy ground gear, and large $(60 \mathrm{~cm}$ diameter) steel bobbins, which are designed to roll over rough ground. Trawl composition, and photographic data indicate the trawled regions of seamounts become barren, with few large benthic animals remaining. Such observations, together with what is known of the impacts of fishing in shallower waters, is resulting in an increasing level of concern, and overdue research on seamount ecology, and the effects of fishing, in New Zcaland.

\section{CONCLUSIONS}

Seamounts are important habitats for deepwater fish species like orange roughy in New Zealand. They are readily identifiable bathymetric features, and so provide a focal point for both the fish, and the fishery. Aggregations of orange roughy can be rapidly overfished, and serial depletion of stocks can occur in which a seamount is located, fished heavily, and then left as catches decline and the fishery moves onto new seamounts. This makes effective management difficult, but individual seamount catch levels can be successfully applied to limit the amount of fishing.

The effects of trawling on seamount communities has received little attention to date in New Zealand, despite their unique and diverse fauna, and the low productivity expected in deeper water. New Zealand has no policy of protecting some seamounts, but following the lead of Australia [12, 13] and the USA, creating reserve areas should be seriously considered to maintain biodiversity, and through further research learn more about the dynamics, functioning, and long-term sustainability of seamount ecosystems.

\section{Acknowledgements}

Thanks to Owen Anderson for assistance with draughting figures, Ralph Coburn for access to some CPUE data, and to Don Robertson (all NIWA) for useful comments on the manuscript. Some of this work was funded by the New Zealand Ministry of Fisheries (project DEOR02) during 1997 and by the Foundation for Research, Science and Technology (contract C01808) during 1998. 
11) Annala J.H., Sullivan K.J. (comps) Report from the Fishery Assessment Plenary, May 1997: stock assessments and yield estimates (available from NIWA, PO Box 14-901, Wellington), 1997.

[2] Clark M.R., Experience with the management of orange roughy (Hoplostethus atlanticus) in New Zealand, and the effects of commercial fishing on stocks over the period 1980 1993, in: Hopper A.G. (Ed.), Deep-water fisheries of the North Atlantic oceanic slope, Kluwer, Netherlands, 1995, pp. 251266.

131 Clark M.R., Biomass estimation of orange roughy: a summary and evaluation of techniques for measuring stock size of a deep-water fish species in New Zealand, J. Fish Biol. 49a (1996) 114-131.

[4] Clark M.R., Fincham D.J., Tracey D.M., Fecundity of orange roughy (Hoplostethus atlanticus) in New Zealand waters, N.Z.J. Mar. Freshwater Res. 28 (1994) 193-200.

[5] Dayton P.K., Thrush S.F., Agardy M.T., Hofman R.J., Viewpoint: environmental effects of marine fishing, Aq. Cons: Mar. Freshwater Eco. 5 (1995) 205-232.

[6] Doonan I.J., Orange roughy fishery assessment, CPUE analysis - linear regression, NE Chatham Rise 1991, N.Z. Fish. Assess. Res. Doc. 91/9, 1991, 48 p. (available from NIWA, PO Box 14-901, Wellington).

[7] F.pp D., Smont N.C., Distribution of seamounts in the North Allantic, Nature 337 (1989) 254257.

[8] Francis R.I.C.C., Robertson D.A., Assessment of the ORH 3B orange roughy fishery for the 1991-92 season, N.Z. Fish. Assess. Res. Doc. 91/3 (1991) 35 p. (available from NWA, PO Box 14-901, Wellington).

[9] Francis R.I.C.C., Robertson D.A., Clark M.R., Coburn R.P., Assessment of the ORH $3 \mathrm{~B}$ orange roughy fishery for the 1992/93 fishing year, N.Z. Fish. Assess. Res. Doc. 92/4., 1992, 45 p. (available from NIWA, PO Box 14-901, Wellington).

[10] Jones J.B., Environmental impact of trawling on the seabed: a review, N.Z. J. Mar. Freshwater Res. 26 (1992) 59-67.
[11] Keating B.H., Fryer P., Batiza R., Buehlert G.W. (Eds.), Seamounts, islands, and atols, Geo. Mono. 43, 1987, $405 \mathrm{p}$.

[12] Koslow J.A., Exon N., Seamount discoveries prompt calls for exploration and conservation, Aust. Fish., Feb. (1995) 10-13.

[13] Koslow J.A., Gowleti-Jones K., The seamount fauna off southem Tasmania: benthic communities, their conservation and impacts of trawling, Final report to Environment Australia and the Fisheries Research Development Corporation, Australia, 1998.

[14] Mace P.M., Fenaughty J.M., Coburn R.P., Doonan I.J., Growth and productivity of orange roughy (Hoplostethus atlanticus) on the North Chatham Rise, N.Z. J. Mar. Freshwater Res. 24 (1990) 105-119.

[15] Probert P.K., McKnight D.G., Grove S.L. Benthic invertebrate bycalch fron a deep-water trawl fishery, Chadhan Rise, New Zealand, Aq. Cons: Mar. Freshwater Eco. 7 (1997) 27-40.

[16] Rogers A.D., The biology of seamounts, Adv. Mar. Biol. 30 (1994) $305-350$.

[17] Sasaki T., Development and present status of Japanese traw] fisheries in the vicinity of seamounts, in: Environment and resources of seamounts in the North Pacific, Uchida R.N., Hayasi S., Boehlert G.W. (Eds.). NOAA Tech. Rep. NMFS 43 (1986) $21-30$.

[18] Smith D.C., Fenton G.E., Robertson S.G., Short S.A., Age determination and growth of orange roughy (Hoplostethus atlunticus): a comparison of annulus counts with radiometric ageing, Can. J. Fish. Aquat. Sci. 52 (1995) 391-401.

[19] Tracey D.M., Horn P.L., Background and review of ageing orange roughy (Hoplostethus atlanticus, Trachichthyidae) from New Zealand and elsewhere, N. Z. J. Mar. Freshwater Res. 33 (1999) 67-86.

$120\rceil$ Uchida R.N., Hayasi S., Boehlert G.W. (Eds.) Environmeni and resources of seamounts in the North Pacific, NOAA Tech. Rep. NMFS 43, 1986, 105 p. 